\title{
Effect of flurbiprofen on the metabolism of antipyrine in man
}

\author{
I. M. CHALMERS, M. A. BELL, AND W. W. BUCHANAN \\ From the Centre for Rheumatic Diseases and University Department of Medicine, Royal Infirmary \\ Glasgow G4 OEH
}

At the present time, there is a proliferation of new drugs for use in rheumatoid arthritis. Because pain in this condition is so difficult to control, most patients are taking two or more drugs simultaneously. It has become clear during recent years that drugs may interact with one another, for example with absorption, protein-binding in plasma, competition at receptor sites, and renal excretion (Prescott, 1969; Jeremy and Towson, 1970; Neuvonen, Gothoni, Hackman and Bjorksten, 1970; Beeley and Kendall, 1971; Kendall, Nutter and Hawkins, 1971). Drugs also interact by the interference of one with the metabolism of another (Conney, 1967 and 1969; Prescott, 1969 and 1971; McEwen and Stevenson, 1972), and several antirheumatic drugs (e.g. phenylbutazone) are known to produce such interactions by the induction of liver microsomal enzymes. It is important therefore to determine whether a new antirheumatic agent may influence the activity of microsomal enzymes.

The rate of disappearance of antipyrine from the plasma after a single oral dose has been shown to be a useful indicator in man of the drug-metabolizing capacity of the liver (O'Malley, Stevenson, and Alexander, 1970). Antipyrine is well-suited for this purpose as it is almost completely metabolized by the liver (Brodie and Axelrod, 1950) and there is little plasma protein binding (Soberman, Brodie, Levy, Axelrod, Hollander, and Steele, 1949). The clearance of antipyrine from the plasma is increased by known inducers of hepatic microsomal enzymes, e.g. phenobarbitone and insecticides (Vessel and Page, 1969; Kolmodin, Azarnoff, and Sjoqvist, 1969).

Flurbiprofen is a newly introduced antirheumatic agent which has been shown in a double-blind controlled trial to be effective in rheumatoid arthritis (Chalmers, Cathcart, Kumar, Dick, and Buchanan, 1972). In this paper, we report the results of a study of the effects of this drug on antipyrine clearance in healthy, normal subjects.

Accepted for publication July 20, 1972

\section{Material and methods}

SUBJECTS

The study was performed on thirteen healthy young volunteers, seven males and six females. All were aged 20 or 21 years and all were Caucasian.

EXPERIMENTAL PROCEDURE

All subjects were seen on three occasions with intervals of $\vec{\varphi}$ 14 days between each visit. Each subject, having fasteg overnight, ingested an oral dose of antipyrine of $18 \mathrm{mg}$. $/ \mathrm{k}$ body weight, at 08.00 hours. Serial blood samples wem withdrawn at $09.30,11.00,12.00,14.00,15.30$ and 17. hours. Each sample was anticoagulated with lithiumheparin and centrifuged as soon as possible after withdrawal. Supernatant plasma was decanted and stored under refrigeration at $4{ }^{\circ} \mathrm{C}$. pending antipyrine estimation which was performed the following day.

Samples withdrawn on the first two occasions were used for a study of the reproducibility of the technique. At the end of the second visit, each subject was issued with a 2week supply of flurbiprofen $(60 \mathrm{mg}$./day for females and $75 \mathrm{mg}$ /day for males). The plasma samples withdrawn during the third visit were used for a study of the influence of flurbiprofen on antipyrine metabolism.

ANTIPYRINE ESTIMATION

This was performed according to the method of Brodie, $O$ Axelrod, Soberman, and Levy (1949). Each estimation was performed in duplicate and standards were run with $\frac{D}{0}$ each set of determinations. Before this study was begun, the precision of the method was tested by performing $\mathrm{N}$ duplicate estimations on 22 plasma samples containing various amounts of antipyrine ( 4 to $40 \mu \mathrm{g} / \mathrm{ml}$.). The mean 요 value \pm standard error for the first set of estimations was $N$

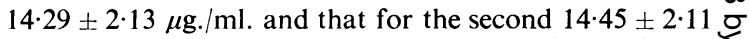
$\mu \mathrm{g} . / \mathrm{ml}$. The difference between these two figures is not 0 significant by the Student's t-test for paired variables $(\mathrm{t}=1 \cdot 20 ; \mathrm{P}>0 \cdot 1)$, which confirms the precision of the method. In order to exclude the possibility of interference by flurbiprofen with the analytical procedure, measured quantities of antipyrine were added to samples of plasma taken from patients before and after administration of therapeutic doses of flurbiprofen. Estimation of antipyrine $\mathbb{Q}$ in these samples revealed no difference between those with and those without flurbiprofen. 


\section{Results}

The values obtained from the antipyrine estimations were used to determine plasma half-lives of the substance for each of the thirteen subjects at each of their three visits (see Table). The male subjects did not differ significantly from the females and all thirteen sets of figures are thus considered together. The mean plasma half-life \pm standard error obtained on the first occasion was $8.5 \pm 1.1 \mathrm{hrs}$ and that obtained on the second occasion $7 \cdot 1 \pm 1 \cdot 0 \mathrm{hrs}$. These two pre-treatment figures do not differ significantly $(\mathrm{t}=1.02 ; \mathrm{P}>0.1)$ but there was wide individual variation (range 1.9 to $15.6 \mathrm{hrs}$ ). The combined mean for all pre-treatment values was $7.9 \pm 0.8 \mathrm{hrs}$. This differed significantly from the mean plasma antipyrine half-life of $14.0 \pm 1.6 \mathrm{hrs}$ obtained after 2 weeks' treatment with flurbiprofen $(t=3.91$; $P<$ 0.01).

\section{Discussion}

A number of drugs and other compounds are known to influence hepatic microsomal enzymes. Of the antirheumatic drugs, phenylbutazone has been the most widely studied, and has been shown to have enzyme-inducing properties in animals (in vitro and in vivo) and in man (Chen, Vrindten, Dayton, and Burns, 1962; Conney, 1967; Kitagawa, Kamataki, and Yoshida, 1968). There is some evidence from animal experiments that corticosteroids may have a similar effect, but aspirin does not (Berlin and Schimke, 1965; Burns, Cucinell, Koster, and Conney, 1965). To our knowledge, the effect of other antirheumatic agents on hepatic drug-metabolizing enzymes has not been investigated, although several are known to inhibit lysosomal acid hydrolases from the liver (Anderson, 1968). Since both aspirin and phenylbutazone have this inhibitory effect on lysosomal enzymes, this finding probably has no relevance to the study of drug metabolism.

The measurement of the plasma half-life of a drug is currently the most acceptable method of studying drug metabolism in man, and antipyrine is probably the most suitable agent for use in such studies (McEwen and Stevenson, 1972). In the present study, in healthy subjects not receiving specific medication, the mean plasma half-life of antipyrine did not vary significantly over a 14-day period. However, for individual subjects, quite markedly different values were obtained for the two measurements. In eight subjects, the half-life decreased by 0.2 to $11.0 \mathrm{hrs}$ and in five it increased by 1.4 to $2.9 \mathrm{hrs}$. These figures support the use of antipyrine in studies of groups, but suggest that figures from individual subjects should ke interpreted with caution because of an apparently random temporal variation.

After 14 days' treatment with flurbiprofen, there was a significant increase in mean antipyrine half-life. This finding suggests that the metabolism of antipyrine is inhibited by flurbiprofen. A possible mechanism for this is the inhibition of hepatic microsomal enzymes, although other influences on the liver cannot be excluded. Alterations in absorption and plasma-binding are unlikely, in view of the known properties of antipyrine (Soberman and others, 1949; Brodie and Axelrod, 1950). From the results obtained in the present study, we have been able to deduce that flurbiprofen produces no appreciable alteration in the volume of distribution of the test substance.

If enzyme inhibition does occur with the administration of flurbiprofen, an important practical implication is that the effect of concurrently adminis-

Table Plasma antipyrine half-lives before and after treatment with flurbiprofen

\begin{tabular}{|c|c|c|c|c|c|c|}
\hline \multirow[t]{2}{*}{ Sex } & \multirow[t]{2}{*}{ Case no. } & \multicolumn{3}{|c|}{ Pre-treatment value } & \multirow{2}{*}{$\begin{array}{l}\text { Post-treatment } \\
\text { value }\end{array}$} & \multirow{2}{*}{$\begin{array}{l}\text { Percentage } \\
\text { change after } \\
\text { treatment }\end{array}$} \\
\hline & & First & Second & Mean & & \\
\hline Male & $\begin{array}{l}1 \\
2 \\
3 \\
4 \\
5 \\
6 \\
7\end{array}$ & $\begin{array}{r}3.9 \\
13 \cdot 7 \\
3.4 \\
6 \cdot 7 \\
7 \cdot 7 \\
15.6 \\
8.8\end{array}$ & $\begin{array}{l}5 \cdot 3 \\
8 \cdot 7 \\
5 \cdot 2 \\
9 \cdot 5 \\
7 \cdot 5 \\
4 \cdot 6 \\
3 \cdot 8\end{array}$ & $\begin{array}{r}4 \cdot 6 \\
11 \cdot 2 \\
4 \cdot 3 \\
8 \cdot 1 \\
7 \cdot 6 \\
11 \cdot 1 \\
6 \cdot 3\end{array}$ & $\begin{array}{r}23 \cdot 3 \\
15 \cdot 8 \\
8 \cdot 2 \\
14 \cdot 6 \\
13 \cdot 7 \\
15 \cdot 2 \\
10 \cdot 2\end{array}$ & $\begin{array}{l}+407 \\
+41 \\
+91 \\
+80 \\
+80 \\
+37 \\
+62\end{array}$ \\
\hline Female & $\begin{array}{l}1 \\
2 \\
3 \\
4 \\
5 \\
6\end{array}$ & $\begin{array}{r}6.5 \\
9.5 \\
5.4 \\
14.6 \\
5.8 \\
8.7\end{array}$ & $\begin{array}{r}1.9 \\
3.9 \\
12.3 \\
13.2 \\
5.3 \\
11.6\end{array}$ & $\begin{array}{r}4 \cdot 2 \\
6.7 \\
8.9 \\
13.9 \\
5.6 \\
10 \cdot 2\end{array}$ & $\begin{array}{r}6.2 \\
7.8 \\
15.0 \\
21.7 \\
21.8 \\
8.6\end{array}$ & $\begin{array}{l}+48 \\
+16 \\
+69 \\
+56 \\
+289 \\
-16\end{array}$ \\
\hline $\begin{array}{l}\text { Mean } \\
\pm \text { SEM }\end{array}$ & & $\begin{array}{r}8 \cdot 5 \\
\pm 1 \cdot 1\end{array}$ & $\begin{array}{r}7 \cdot 1 \\
\pm 1 \cdot 0\end{array}$ & $\begin{array}{r}7.9 \\
\pm 0.8\end{array}$ & $\begin{array}{l}14 \cdot 0 \\
\pm 1 \cdot 6\end{array}$ & $\begin{array}{r}97 \\
\pm 33\end{array}$ \\
\hline
\end{tabular}


tered drugs may be prolonged. This phenomenon is well recognized for other therapeutic agents, such as isoniazid, chloramphenical, nortriptyline, and dicoumarol (Hansen, Kristensen, Skovsted, and Christensen, 1966; Kristensen and Hansen, 1967; Koch-Weser and Sellers, 1971 ; Kutt, 1971). Clinically significant interactions as a result of hepatic enzyme inhibition have occurred in many patients with chronic diseases who have been treated with these drugs. Another possibility is that flurbiprofen may inhibit its own metabolism and accumulate if given in the doses used in this study. A further interpretation of the present findings is that the change produced by the drug may be an early manifestation of hepatotoxicity (Sasame, Castro, and Gillette, 1968). However, no clinical or biochemical evidence of liver damage has been evident in twenty patients treated with therapetuic doses of flurbiprofen for up to 9 months (Cathcart, 1972). Further investigations of the effect of flurbiprofen on hepatic microsomal enzymes appear to be warranted, and clinical studies to detect possible accumulation of the drug are also indicated.

\section{Summary}

A study in healthy young volunteers of the plasma half-life of antipyrine has shown that this is significantly increased after administration of the new antirheumatic drug, flurbiprofen. This finding suggests a possible inhibitory effect of the drug on hepatic $\%$ microsomal enzymes. This, in turn, could con- $\overrightarrow{0}$ ceivably produce a prolongation of the action of $\rightarrow$ flurbiprofen itself and of other drugs metabolized by the liver.

The authors gratefully acknowledge the financial support of the Arthritis and Rheumatism Council for Research and ${ }_{\infty}$ the Boots Company Limited. We also wish to thank Dr. A. A. J. Goldberg of the Boots Company Limited for his assistance and for providing supplies of flurbiprofen.

\section{References}

Anderson, A. J. (1968) Biochem. Pharmacol., 17, 2253 (The effect of anti-inflammatory drugs on the enzymic activity of a rat liver granular fraction which increases vascular permeability)

BeEley, L., AND KeNDALL, M. J. (1971) Brit. med.J., 1, 707 (Effect of aspirin in renal clearance of ${ }^{125}$ I-diatrizoate)

Berlin, C. M., AND SChimke, R. T. (1965) Molec. Pharmacol., 1, 149 (Influence of turnover rates on the responses of enzymes to cortisone)

Brodie, B. B., AND AXelrod, J. (1950) J. Pharmacol. exp. Ther., 98, 97 (The fate of antipyrine in man)

,-- Soberman, R., AND LeVY, B. B. (1949) J. biol. Chem., 179, 25 (The estimation of antipyrine in biological materials)

Burns, J. J., Cucinell, S. A., Koster, R., and Conney, A. H. (1965) Ann. N.Y. Acad. Sci., 123, 273 (Application of drug metabolism to drug toxicity studies)

CAthCART, B. J. (1972) Personal communication

Chalmers, I. M., Cathcart, B. J., Kumar, E. B., Dick, W. C., and Buchanan, W. W. (1972) Ann. rheum. Dis., 31, 319 (Clinico-pharmacological studies and clinical evaluation of flurbiprofen, a new non-steroidal analgesic drug)

Chen, W., Vrindten, P. A., Dayton, P. G., and Burns, J. J. (1962) Life Sci., 2, 35 (Accelerated aminopyrine metabolism in human subjects pretreated with phenylbutazone)

Conney, A. H. (1967) Pharmacol. Rev., 19, 317 (Pharmacological implications of microsomal enzyme induction) (1969) New Engl. J. Med., 280, 653 (Drug metabolism and therapeutics)

Hansen, J. M., Kristensen, M., Skovsted, L., And Christensen, L. K. (1966) Lancet, 2, 265 (Dicoumarol-induced diphenylhydantoin intoxication)

Jeremy, R., AND Towson, J. (1970) Med.J. Aust., 2, 127 (Interaction between aspirin and indomethacin in the treatment of rheumatoid arthritis)

Kendali, M. J., Nutter, S., AND Hawkins, C. F. (1971) Brit. med. J., 1, 533. (Xylose test: effect of aspirin and indomethacin)

Kitagawa, H., Kamataki, T., and Yoshida, S. (1968) Chem. pharm. Bull., 16, 2320 (Studies on drug metabolism. IV. Effects of high dose administration of pentobarbital and phenylbutazone on the plasma biologic half lives in various species)

Koch-Weser, J., AND Sellers, E. M. (1971) New Engl.J. Med., 285, 487, 547 (Drug interactions with coumarin anticoagulants)

Kolmodin, B., Azarnoff, D. L., and Sjoqvist, F. (1969) Clin. Pharmacol. Ther., 10, 638 (Effect of environmental factors on drug metabolism: decreased plasma half-life of antipyrine in workers exposed to chlorinated hydrocarbon insecticides)

Kristensen, M., AND HANSEN, J. M. (1967) Diabetes, 16, 211 (Potentiation of the tolbutamide effect by dicoumarol)

KuTt, H. (1971) Ann. N.Y. Acad. Sci., 179, 704 (Biochemical and genetic factors regulating dilantin metabolism in man)

McEwen, J., And Stevenson, I. H. (1971) Scot. med. J., 17, 67 (Drug metabolism)

Neuvonen, P. J., Gothoni, G., Hackman, R., AND BJörksten, K. A. (1970) Brit. med. J., 4, 532 (Interference of iron with the absorption of tetracyclines in man) 
O’Malley, K., Stevenson, I. H., AND AleXander, W. (1970) Scot. med. J., 15, 454 (Increased antipyrine half-life in women taking oral contraceptives)

PresCOTT, L. F. (1969) Lancet, 2, 1239 (Pharmacokinetic drug interactions)

- (1971) Scot. med.J., 16, 121 (Drug metabolism and therapeutics)

Sasame, H. A., Castro, J. A., AND Gillette, J. R. (1968) Biochem. Pharmacol., 17, 1759 (Studies on the destruction of liver microsomal cytochrome P-450 by carbon tetrachloride administration)

Soberman, R., Brodie, B. B., Levy, B. B., AXelrod, J., Hollander, V., AND Steele, J. M. (1949) J. biol. Chem., 179,31 (The use of antipyrine in the measurement of total body water in man)

Vessel, E. S., AND PAGE, J. G. (1969) J. clin. Invest., 48, 2202 (Genetic control of the phenobarbital-induced shortening of plasma antipyrine half-lives in man) 